\title{
Fleksibilitas Negara Hukum Ala al-Qur'an dan Implementasinya Pada Masa Kini
}

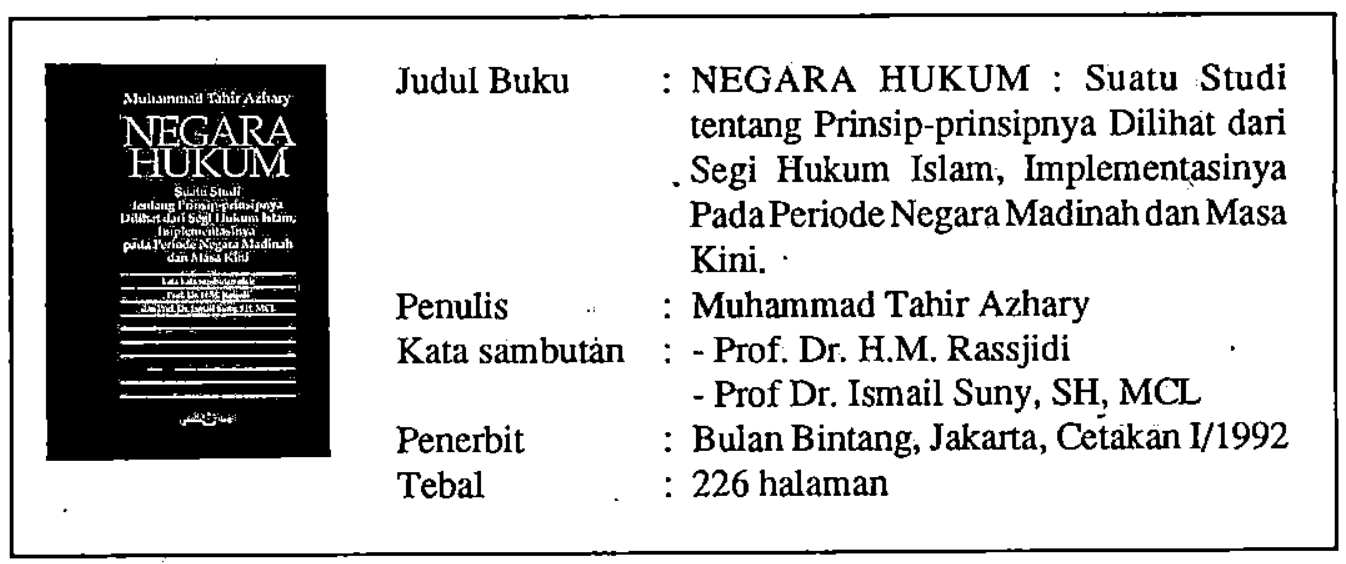

Kegelisahän yang dihadapi oleh kalangan yang ingin mendalami teori-teori Islam mengenai Politik dan Kenegaraan adalah karena terbatasnyakhasanah literatur mengenai masalah ini. Hal inilah yang menyebabkanmereka kecewa dan seolaholah tidak interest lagi dalam persoalan ini: Ironis memang, mengapa pada masa keemasan Islam tidak mewariskan literatur yang memadai di bidang studi politik dan Kenegaraan ini. Pertanyaan inilah yang selalu dilontarkan oleh para peminat di bidang, ini yang selama ini belum memperoleh jawaban yang memuaskan. Namun begitu, kiranya patut disimak pendapat Ahmad Syalabi, seorang Guru besar pada Cairo University yang menyatakån ada dua kemungkinan yang menyebabkan langkanya warisan intelektual Islam di bidang ini, yakni : Pertama, dimusnahkannya perpustakaahperpustakaan Abbasiyah yang pernah memiliki khasanah yang cukup memadai dalam bidang ini oleh orang-orang Mongol pada tahun 1258; Kedua, rezim-rezim. kesultanan yang berwatak sangat otoriter dan tidak mentolerir, " intelectual exercise' di bidang Politik, Kenegaraan, serta perubahan sosial sehingga yang muncul ke permukaan hanyalah ijtihad di bidang Fiqh an-Sich. Oleh karena itu tidak heran jika literatur di bidang Figh misalnya, ataupun masalah Teologi dan Filsafat hampirhampir tak terbatas. Bahkan pembahasan masalah Politik dan Kenegaraan inimenjadi bagian dari pembahasan ketiga bidang tersebut (Fiqh, Teologi dan Filsafat), dan tidak pernah dibahas secara spesifik dan komprenhensif.

Buku ini, yang diangkat dari disertasi Muhammad Tahir Azhary yang telah dipertahankannya untuk meraih gelar Doktor dalam Ilmu Hukum pada Fakultas Hukum Universitas Indonesia pada tanggal 9 Maret 1991, minimal dapat mengurangi kegelisahan kalangan para peminat teoriteori Islam di bidang Politik dan Kenegaraan tersebut. Karena kajian yang diangkat termasuk amat langka atau bahkan mungkin untuk pertama kalinya dibuat (KOMPAS, 
I6 Maret 1991), halaman 6). Prof. Dr. Ismail Suny,SH,MCL dalam kata sambutannya meyatakan bahwa penelitian yang dilakukan oleh Muhammad Tahir Azhary dilihat dari sudut studi tentang Negara dan Hukum Tata Negara yang dihubungkan dengan Islam, merupakan yang pertama dilakukan pada Universitas Indonesia sebagai pendidikan tinggi yang bersifat umum. Karena itu, boleh dikatakan dia adalah Doktor dalam Ilmu Hukum yang pertama yang menulis Disertasi dari sudut Hukum Islam yang pernah dihasilkan oleh Universitas Indonesia (halaman ix).

Penèlitian yang telah dilakukannya dengan mengalani berbagai liku-liku dan proses yang panjang, antara lain dia lakukan di Leidendengan sponsor Nederlandse Raad Voor Juridische Samen Werking Met Indonesia menggambarkan kedalaman ilmunya, baik di bidang hukum umum, hukum islam, ia memperoleh gelar Sarjana Hukum (Jurusan hukum Internasional) dari Universitas Indonesia tahun 1968. Sedangkan bidang ilmu Keislaman dia memperoleh gelar MA dari Institute of Islamic Studies Mc Gill University, Montreal, Canada (1973-1975). Prof. Dr. H.M. Rasjidi berpendapat bahwa dia adalah seorang lawyer yang tidak hanya menguasaibidang hukum umum, tapi juga dia dapat dikualifikasikan sebagai seorang pakar di bidang Keislaman dan Hukum Islam (halaman vii).

\section{Negara, Hukum dan Agama.}

Pendekatan analisis yang dilakukan oleh penulis dalam membahas hubungan antara Negara, Hukum, dan Agama adalah dengan menkomparasikan konsep al-din al-Islami menurut al-Qur'an, dan konsep religion menurut pemahäman barat serta konsep hukum, baikdari sudut Islam, maupun barat.
Penulis berpendapat bahwa konsep negara di Eropa Barat telah mengalami proses panjang yang semula ditandai kekosongan doktrin negara dalam Agama Kristen, kerena sejak lahimya agama ini telah memisahkan kekuasaaan negara dari gereja. Kemudian dalam proses perkembangan agama kristen selama abad pertengahan, agama ini di Eropa telah menduduki posisi yang sangat dominan dalam kehidupan negara. Secara ringkas proses pemikiran tentang negara Barat adalah melalui; Keadaan vakum konsep negara dalam agama Kristen, teori teokrasi dengan berbagai variasinya dari Augustinus, Thomas Aquinas dan lain-lain, rekasi terhadap teori teokrasi (mulai proses sekularisasi), dan negara sekuler (halaman 30). Berbeda sekali proses pemikiran tentang negara dalam konsepsi Islam. Karena Muhammad di samping sebagai Nabi, beliau juga seorang prajurit sekaligus Negarawan, Kepala Pemerintahan, dan pendiri suatu negara. Oleh karena itu patut dikemukakan pandangan dari beberapa sarjana muslim maupun sarjana barat yang non muslim (tentu saja mereka yang pro dengan konsepsi ini), mereka sepakat bahwa sejak agama Islam lahir, antara agama dan negara selalu ada kaitan yang erat. Salah satu doktrin alQur'an yang memperkuat pendirian ini adalah "hablun min Allah wa hablun min al-nas" yang merupakan satu kesatuan (halaman 38). Doktrin inilah yang memperkuat pendirian penulis, bahwa dalam Islam, agama dan negara mempunyai pertalian yang erat, didukung oleh fakta sejarah selama masa Rasulullah dan Khulafa' Rasyidin selama periode Negara Madinah merupakan bukti-bukti yang kuat, bahwa agama Islam sejak lahimya selalu berkaitan dengan aspek-aspek kenegaraan dan kemasyarakatan. 
Berkaitan dengan masalah hubungan antara hukum dengan agama, penulislebih lanjut mengemukakan bahwa pada saat ini, hukum dan agama dalam konteks pemikiran barat sudah tidak lagi memiliki kaitan yang erat. Keadaan ini disebabkan karena pengaruh rasionalisme dan Aufklanung yang sangat dominan. Meskipun juga masih ada sarjana barat, seperti Fredrich Julius Stahl masih mengakui adanya pengaruh agama terhadap hukum, namun tampakanya ajarannya pada masa kini secara umum tidak membekas lagi dalam pemikiran para ahli hukum di barat (halaman 38). Hal ini sangat berbeda dengan pendekatan pemikiran Islam yang sama sekali tidak mengasingkan agama dari "wilayah hukum". Secara umum, pandangan para sarjana muslim sepakat bahwa ada kaitan yang sangat erat antara agama dan hukum. Karena dalam Islam, hukum adalah satu sektor dari al-din al-Islami. Dengan demikian, maka dalam konteks pemikiran - Islam, negara dan hukum sangat berkaitan erat dengan agama. Dalam Islam tidak dikenal dikhotomi, baik antara agama dan negara maupun antara agama dan hukum. Dalam kaitan ini pula, penulis mengintrodusir suatu teori yang dinamakannya "Teori Lingkaran Konsentris", dimana ketiga komponen itu agama, hukum, dan negara - apabila disatukan akan' membentuk lingkaran konsentris yang merupakan satu kesatuan dan berkaitaneratantara satu dengan lainnya (halaman 43).

Prinsip-prinsip Negara hukum dan Implementasinya

Mengawali pembahasan ini, penulis menemukan dalam penelitiannya itu ada lima macam konsep negara hukum, yaitu: Negara Hukum menurut Qur'an dan Sunnah (yang selanjutnya disebut dengan Nomokrasi Islam). Negara Hukum menurùt konsep Eropa Kontinental (rechtsstaat), Konsep rule of law di negara-negara AngloSaxon, Konsep Socialist Legality, dan Konsep.Negara Hukum Pancasila. Kelima konsep negara hukum tersebut, disajikannyadalam bentukstudikomparatif pada pembahasan berikutnya. khusus mengenai Nomokrasi Islam, yaitu suatu negara hukum menurut Qur'an dan Sunnah, menurutnya ada sembilan prinsip umum yaitu: Prinsip kekuasaan sebagai amanah, Prinsip musyawarah, Prinsip keadilan, Prinsip persamaan, Prinsip pengakúan dan perlindungan terhadap hak-hak azasi manusia, Prinsip peradilan bebas, Prinsip perdamaian,Prinsip kesejahteraan, dan Prinsip ketaatan rakyat (halaman 64). Terhadap kesembilan prinsip tersebut, penulis mengadakan analisis secara detil dari al-Qur'an maupun al-Sunnah, dan penulis sajikan dalam BAB IV dari buku ini.

Sampai pada masalah implementasi prinsip-prinsip negara hukum, dimana penulis menyajikan suatu analisis tentang implementasi prisnsip-prinsip negara hukum tersebut menurut al-Qur'an dan Sunnah Rasulullah selama masa Pemerintahan Nabi Muhammad saw pada periode Negara Madinah, dan pasca masa Pemerintahan Rasulullah, yaitu masa Khulafa'Rasyidin (BAB IV): Dia juga menyajikan suatu analisis tentang implementasi sejumlah prinsip Nomokrasi Islam yang ada relevansinya dengan. konstitusi-konstitusi Indonesia, Malaysia, Saudi Arabia, pakistan, dän Mesir yang notabene sebagai negara-negara muslim. Kecuali itu akan dikaji pula implementasi beberapa prinsip negara hukum di negara- negara barat seperti Belanda, Perancis, 
Inggris dan Amerika Serikat (BAB VI).

Keilmiahan buku setebal 226 halaman ini tidak perlu diragukan lagi karena ditulis oleh seorang akademikus yang cukup mumpuni pada bidangnya sebagaimana telah dijelaskan di muka, di samping itu pula sebelum karyanya ini diterbitkan, ia bersama Prof. H. Daud Ali. SH, dan Ny. Habibah Daud, SH, telah bertindak sebagai Co-author búku Islam untuk disiplin ilmu hukum, sosial dan politik (Jakarta: Bulan Bintang, 1988). Tulisan-tulisannya telah tersebardalam berbagai harian dan majalah; Berita Buana, Sinar Harapan, Majalah Hukum dan Pembangunan, forum Keadilan, Panji Masyarakat, dan lain-lain.
Buku ini sangat layak dibaca oleh para mahasiswa Fakultas Hukum, lebih-lebih bagi para peminat dibidang hukum Islam dan Hukum Tata Negara wajib membaca buku ini agar bisa melakukan studi komparatif secara komprehensif.

Kekurangan buku ini terletak pada penulisan catatan kaki yang ditempatkan pada setiap akhir bab, sehingga agak kesulitan bagai para pembaca ketika akan melacak informasi mengenai sumber bacaan yang dikutip oleh penulis. Namun demikian, kekurangan ini tidak mengurangi nilai penting buku ini.

(Muntoha). 